A HISTORY OF THE ENGLISH LANGUAGE 
Also by N. F. Blake from the publishers

AN INTRODUCTION TO ENGLISH LANGUAGE (with Jean Moorhead)

AN INTRODUCTION TO THE LANGUAGE OF LITERATURE THE LANGUAGE OF SHAKESPEARE 


\title{
A History of the English Language
}

\author{
N. F. BLAKE \\ Professor of English Language \\ University of Sheffield
}




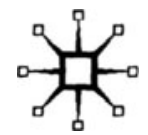

C N.F. Blake 1996

All rights reserved. No reproduction, copy or transmission of this publication may be made without written permission.

No paragraph of this publication may be reproduced, copied or transmitted save with written permission or in accordance with the provisions of the Copyright, Designs and Patents Act 1988, or under the terms of any licence permitting limited copying issued by the Copyright Licensing Agency, 90 Tottenham Court Road, London W1T 4LP.

Any person who does any unauthorised act in relation to this publication may be liable to criminal prosecution and civil claims for damages.

The author has asserted his right to be identified as the author of this work in accordance with the Copyright, Designs and Patents Act 1988.

Published by

PALGRAVE

Houndmills, Basingstoke, Hampshire RG21 6XS and 175 Fifth Avenue, New York, N. Y. 10010

Companies and representatives throughout the world

PALGRAVE is the new global academic imprint of

St. Martin's Press LLC Scholarly and Reference Division and Palgrave Publishers Ltd (formerly Macmillan Press Ltd).

ISBN 978-0-333-60984-2 ISBN 978-1-349-24954-1 (eBook)

DOI 10.1007/978-1-349-24954-1

This book is printed on paper suitable for recycling and made from fully managed and sustained forest sources.

A catalogue record for this book is available from the British Library.

Typeset by Nick Allen/Longworth Editorial Services Longworth, Oxfordshire

Transferred to digital print on demand 2003 


\section{Contents}

Preface

vi

List of Abbreviations viii

List of Maps $\quad \mathbf{x}$

List of Figures $\quad$ xi

1 What is a History of English? 1

2 Background Survey 24

3 Before Alfred 47

4 The First English Standard 75

5 The Aftermath of the First Standard 105

6 Interregnum: Fragmentation and Regrouping 132

7 Political, Social and Pedagogical Background 172 to the New Standard

8 Language Change from 1400 to 1660203

9 Establishing the Standard within Social Norms 236

10 Emancipation, Education and Empire 272

11 World Domination and Growing Variation 303

Notes 333

Suggested Further Reading 339

Appendix

Glossary of technical terms 341

Phonetic script $\quad 350$

Index

General

English words 371 


\section{Preface}

When I was asked to write a history of the English language in one volume for undergraduates and the general public, I was in the middle of editing the second volume of the Cambridge History of the English Language. The work I was doing on that volume prompted me to reconsider the appropriate way to organise a single-volume history of English. I came to the conclusion that it was better to focus on the development of standard English in order to give the volume cohesion and to prevent it from trying to achieve too much. I realise that such a decision makes the resulting work more restricted in its approach in that those who live in Australia might well feel that the contributions that their country had made to the development of English have been overlooked. But my own knowledge of varieties like Australian is limited and the impact of Australian on British English is something that might be better tackled by an Australian. However, the contribution made by and the form of English found in other countries cannot be overlooked and I hope I have made that clear in the final chapter of this present book. In particular, American English has had a considerable influence on British English over the years and so more attention is given to that variety in this book. But even it is seen from the viewpoint of how it has influenced the development of British English. As an editor of one volume of the Cambridge History I have also acted as part of the editorial team for all volumes, and I have gained immeasurably from being immersed in that work. Writers for the Cambridge History have helped me focus my ideas and understand the history of English more clearly. This book is the better for the work done for the Cambridge History and I am grateful to the various contributors to all the volumes who have, unknown to them, made my task with this book easier. I am also grateful to various colleagues in Sheffield, particularly David Burnley and Geoff Lester, for their help with many aspects of this book, and to Dr Robert McNamee for checking some references. Parts of the book have been given as lectures to the International Conferences on English Historical Linguistics and elsewhere, and I am indebted to my audiences for their comments. 
The strategy I have adopted involves abandoning the traditional framework of Old, Middle, Early Modern and Late Modern English in favour of a more flexible format for the book as a whole. However, the concepts Old and Middle English are so ingrained that I have used them where I thought it would make the sense easier for the reader.

It may be appreciated that the approach adopted in this book is my own and I alone am responsible for its overall shape and contents. I hope it will prove stimulating for those who use it, and that it will help to develop that growing interest in the history of the language which has been manifest over the last few years. It is even a topic which is now more taught in schools because of the development of English Language A-levels and the National Curriculum.

N.F. BLAKE 


\section{List of Abbreviations}

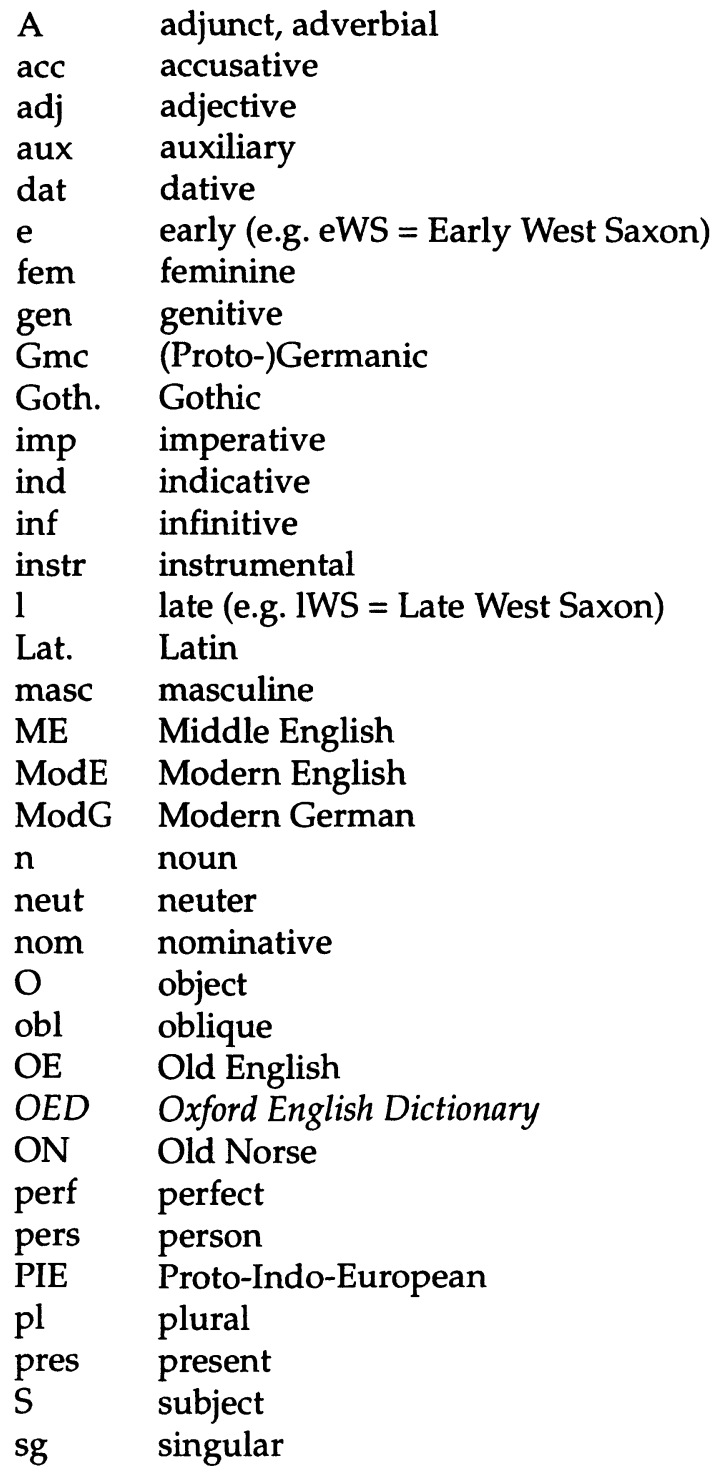




\begin{tabular}{|c|c|}
\hline V & verb \\
\hline WGmc & West Germanic \\
\hline WS & West Saxon \\
\hline * & a reconstructed or hypothetical form \\
\hline ** & an unacceptable form or construction \\
\hline$\varnothing$ & a zero form, an empty slot in the grammatical system \\
\hline I I & a phonemic form \\
\hline [ ] & a phonetic form \\
\hline$<>$ & a graph, i.e. a letter form \\
\hline$<$ & $\begin{array}{l}\text { is developed from (as one sound may be developed } \\
\text { from another) }\end{array}$ \\
\hline$>$ & develops into (as one sound may change to another) \\
\hline (:) & $\begin{array}{l}\text { a sound with or without length (e.g. } e(:) \text { means long } \\
\text { and/or short } e \text { ) }\end{array}$ \\
\hline
\end{tabular}




\section{List of Maps}

1 Anglo-Saxon dialect areas

xii

2 Dialects in the Interregnum xiii

3 English in the world today: countries where xiv English is or has recently been an official language 


\section{List of Figures}

4.1 Cura Pastoralis, King Alfred's preface

6.1 The Canterbury Tales, General Prologue (c.1405) 163

7.1 Letter from Margaret Paston to John Paston (1465) 183

7.2 Love's Labour's Lost, First Folio (1623) 193

7.3 Robert Cawdrey, A Table Alphabeticall (1604) 197

8.1 Edmund Coote, The English Schoolemaister (1596) 231

9.1 Dr Johnson, A Dictionary of the English Language (1755) 253

10.1 J. A. H. Murray, A New English Dictionary on Historical 289 Principles (1888) 


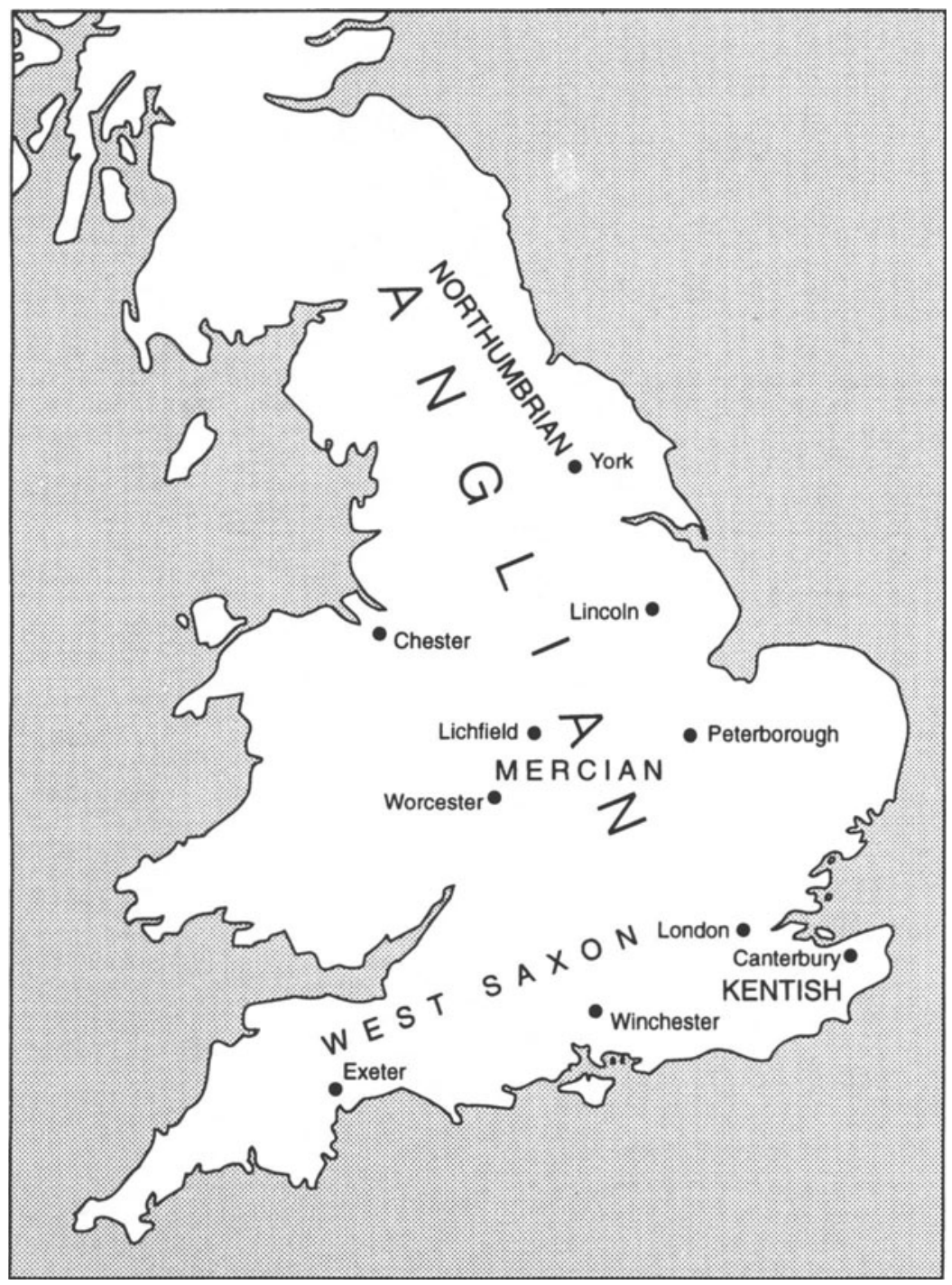

MAP 1 Anglo-Saxon dialect areas 


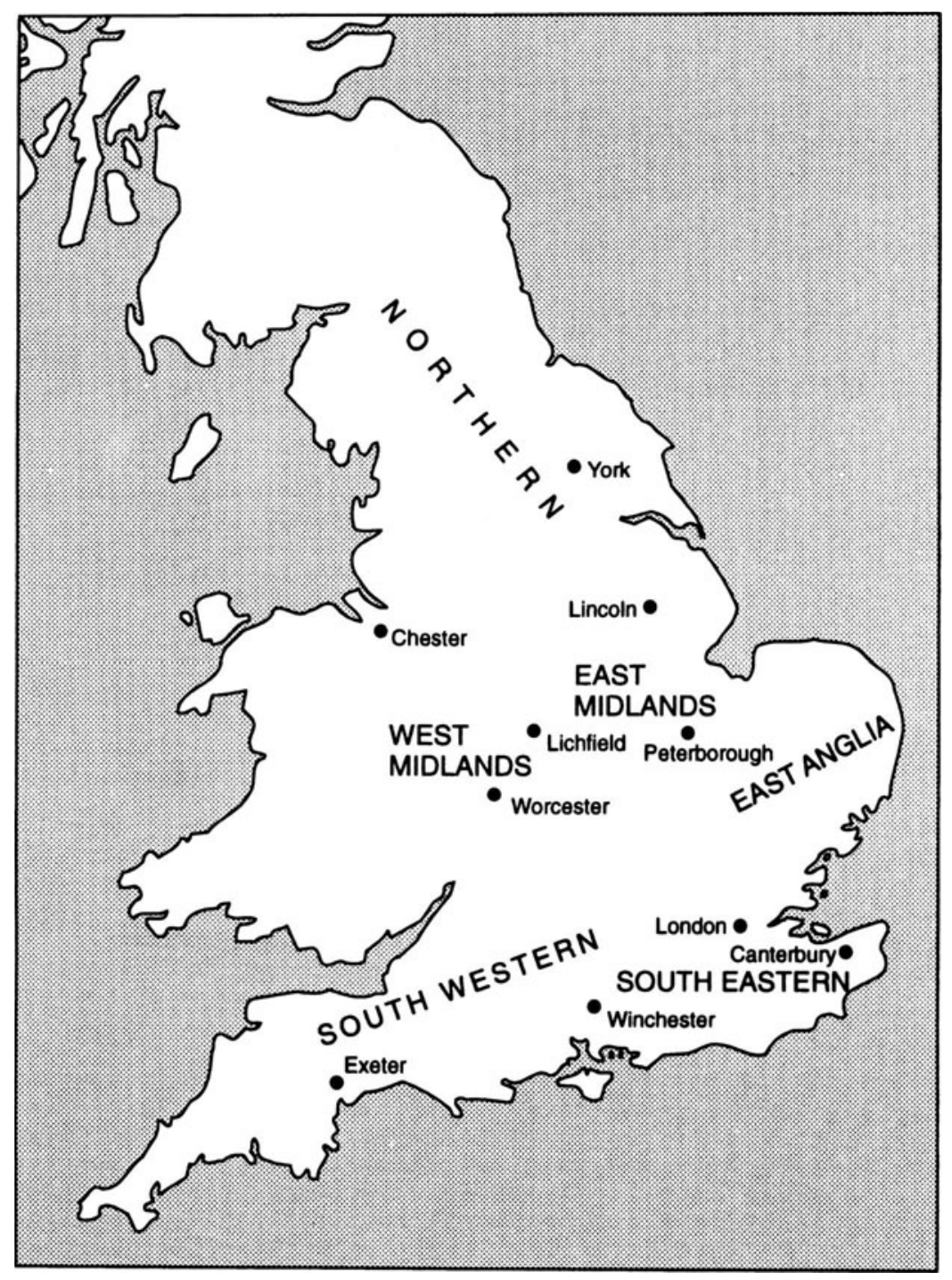

MAP 2 Dialects in the Interregnum 


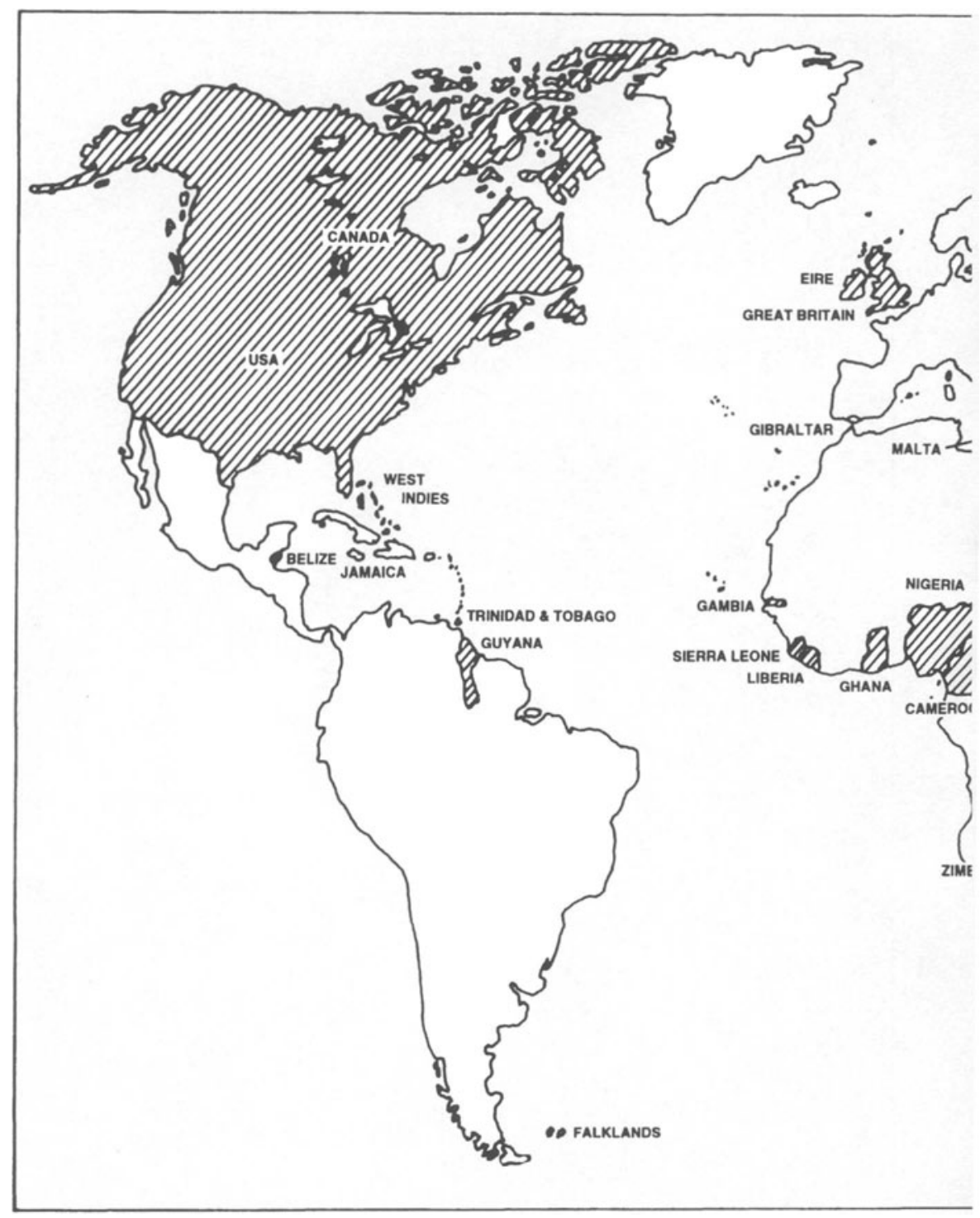

MAP 3 English in the world today: countries where English is or has recently been an official language 


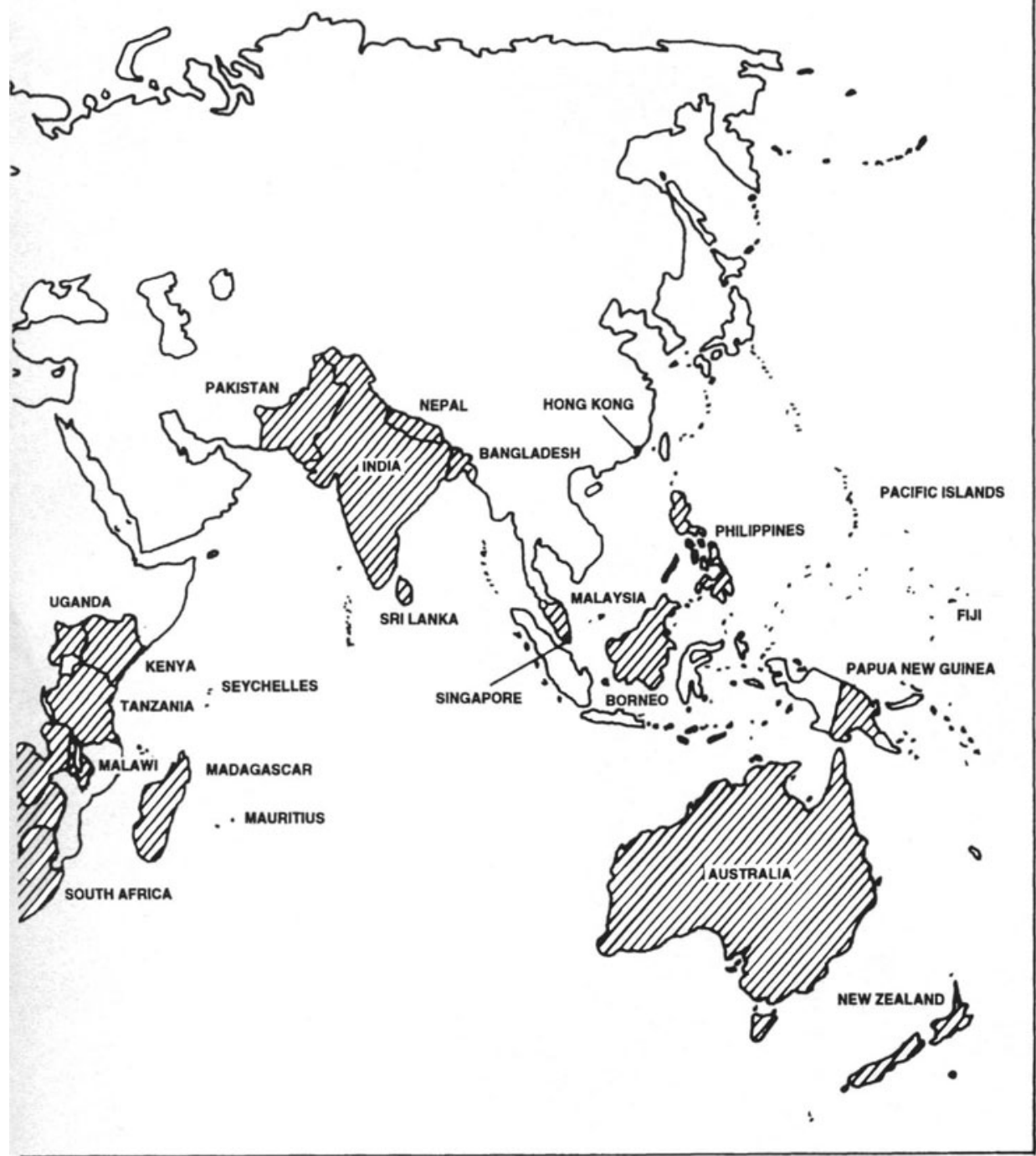

